\title{
MARKETING STRATEGY BY USING SWOT, IFE, EFE, AND QSPM METHOD TO IMPROVE COMPETITIVENESS IN SOERYA BAKERY TULUNGAGUNG
}

\author{
Mega Tunjung Hapsari ${ }^{1}$, Didik Setiawan ${ }^{2}$ \\ Fakultas Ekonomi dan Bisnis Islam IAIN Tulungagung \\ Jl. Mayor Sujadi Timur 46 Tulungagung \\ E-mail : didiksetiawan79724@gmail.com \\ diterima: 12/3/2021; direvisi: 3/4/2021; diterbitkan: 26/9/2021
}

\begin{abstract}
This study aimed to analyze internal and external conditions, to develop and plan appropriate marketing strategies, as well as to improve the business competitiveness of Soerya Bakery Tulungagung. The analytical method employed was a mixed-method, which was a qualitative analysis description based on the results of the Strengths-WeaknessesOpportunities-Threats (SWOT) matrix. Furthermore, it was supported by quantitative analysis using matrices of Internal Factor Evaluation (IFE), External Factor Evaluation (EFE), Internal-External (IE), and Quantitative Strategic Planning Matrix (QSPM). The data collection techniques in this study employed a triangulation technique from three techniques, namely observation, interviews and literature study. The results indicated that the weighted value for the IFE matrix was 2.98 (average position) while the EFE was 3.17 (moderate position). Furthermore, in the IE Matrix, it pointed out that the strategy which should be carried out was growth and build strategy, consisting of intensive strategy (market penetration, market development, and product development) and integrative strategy (backward, forward, and horizontal integrations). Whereas, the priority strategy that might be implemented in developing this business based on the QSPM matrix was intensifying promotions and product information both online offline; improving the quality, quantity, distribution network, and partnerships; as well as opening a new branch.
\end{abstract}

Keywords: Marketing Strategy, SWOT, IFE and EFE, QSPM

\section{INTRODUCTION}

The economy is one of the factors that vividly influence the progress of a country. Each country competes to improve its economic productivity. According to the data sourced from CNBC Indonesia (2019) and Kompas (2020), the Gross Domestic Product of Indonesia is ranked 16th in the world. Meanwhile, viewing from the balance of trading ability or purchasing power parity, Indonesia is currently ranked 7th in the world. Consequently, the significant economic growth in Indonesia is inseparable from the role of Small and Medium Enterprises (SMEs). One of Small and Medium Enterprises (SMEs) is Soerya Bakery Tulungagung, which engaged in a bakery. Nowadays, the bakery business continues to grow, and therefore the company will strive to keep on improving quality and customer satisfaction. One of the most important things in business is related to the implementation of business and marketing strategies. A company is required to make expansion and improvement in order to improve its business. A marketing strategy sets the overall goals and objectives for the marketing division, start from the strategic planning to the evaluation process.

According to Porter in Wheelen (2008:73), environmental and social conditions should be observed to detect strategic factors that tend to have a substantial impact on the company's success or failure. For these 
circumstances, business managers must be able to take advantage of environmental situations in the development of their business. One of the attempts to facilitate the utilization of environmental situations is by analyzing internal and external factors. This analysis is used to determine the strengths and weaknesses, to take advantage of opportunities, and to be aware of possible threats of the company in order to face competitors. Hence, this study was feasible and significant to be carried out because the results could accommodate the results of the strategic factors analysis. It was conducted through the matrix of internal and external environmental factors, which produced an ideal business strategy map for Soerya Bakery SME.

Many researchers have described competitiveness as a multidimensional and relative concept. Having significance of the different criteria, competitiveness changes through time and context. Theories and frameworks have to be relatively flexible to integrate changes with the strategic management process. Despite many theories about competitiveness and interdisciplinary fields related to strategy, resource-based operations, economics, and many others, practitioners do not widely apply those theories in their decisions to improve or maintain competitiveness (Barney $\mathrm{J}, \mathrm{M}$, Wright, and DJ, Ketchen: 2001: 625). Competitiveness can be treated as an either dependent or independent variable, depending on the perspective of the problem. Berkely, et al., (1988: 174) have proposed a framework applying three factors, namely: performance competitiveness, potential competitiveness, and management process. The research results of Meliala, et al., (2014), and Anggraeni, et al., (2017) concluded that marketing strategy planning in SMEs is influenced by human resources, facilities and technology, innovation, and business competitors. In this case, business owners are required to carry out strategic management, comprising of analysis, decisions, and actions to create and maintain a competitive advantage.

Strategy management is a framework that guides choices, which in turn, determines the nature, direction, and goals of the organization. The results of the study provided recommendations for alternative strategies as an effort to improve competitiveness. Meanwhile, the purpose of this study was to analyze internal and external conditions, to produce ideal strategic planning, and to utilize alternative strategies to improve Soerya's Bakery Tulungagung competitiveness.

\section{LITERATURE REVIEW}

Marketing strategy planning involves more detailed planning for more specific marketing opportunities. The success of a company's marketing effort depends on the management's ability to plan its marketing programs strategically. The research of Adewale et al., (2013) on the impact of marketing strategies on SMEs business performance in Nigeria illustrates that products, promotions, places, prices, packaging, and after-sales services are notable joint predictors of business performance in terms of profitability, market share, profit on investment, and expansion. In addition, Ataman et al., (2010); Haris and Rae (2010); Heerde et al., (2013) concluded that social networking and advertising will play a vital role in the future marketing, which externally can increase promotion and product information, and internally help alter the focus of traditional marketing with an open and collaborative approach that is more beneficial in achieving success in a modern business environment. 
Analysis of strengths, weaknesses, opportunities and threats (SWOT) indicates a framework that helps researchers or planners to identify and prioritize business objectives, as well as to identify strategies to achieve them. SWOT analysis is a technique employed to analyze the strengths, weaknesses, opportunities and threats of the business that derive from the internal environment (Internal Factor Evaluation) and external (External Factor Evaluation). In addition, academic researches illustrate that the effectiveness of SWOT can be intensified by using qualitative and quantitative techniques together (Gurel, 2017).

A qualitative investigation of internal and external factors is only the beginning of in-depth analysis in the strategic planning process. Therefore, it is necessary to employ QSPM (Qualitative Strategic Planning Matrix) to select the best strategy for business objectively. Ommani (2011) clarified that QSPM consists of key external and internal factors obtained directly from the IFE and EFE matrices, as well as feasible alternative strategies derived from a SWOT analysis. The results obtained in the process are the precise ideal strategy to be executed in the business.

\section{METHOD}

The stages of marketing strategy research to improve the competitiveness of Soerya Bakery Tulungagung are illustrated in Figure 1:

Figure 1. Scheme of Research Stages

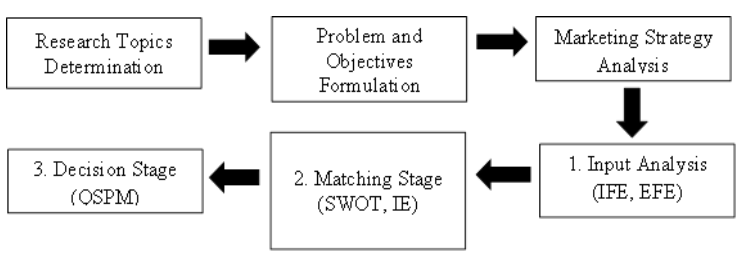

The type of data processing and analysis employed were mixed-methods by exercising sequential exploratory designs. A sequential exploratory design was selected to provide priorities on the quantitative stage; however, it requires starting with qualitative data collection, in the beginning, to be able to identify the focus of potential variables. Moreover, qualitative and quantitative descriptive analyses were carried out based on the strategic management concept approach. The qualitative descriptive analysis was employed to determine a company environment related to the possessed opportunities, threats, strengths, weaknesses of the company and the formulation of strategies employed the SWOT matrix. On the other hand, quantitative analysis engaged the matrices of EFE, IFE, IE, and QSPM.

The data employed were derived from two sources, namely primary data and secondary data. Primary data was collected by researchers directly from the research objects through direct interviews with the manager of Soerya Bakery Tulungagung. In addition, secondary data was obtained from several sources related to the object of this study. Secondary data from this study were the results of previous studies, literature, and data from research objects that were applied in the preparation of this study.

According to David and David (2017), a strategy preparation is carried out through three work stages, namely the input stage (internal and external factor input analysis), the matching stage (SWOT and IE Matrix) and the decision stage (QSPM Matrix). The first stage employed the IFE and EFE matrices. Meanwhile, the matching stage focused on constructing appropriate alternative strategies by matching internal and external factors using the SWOT and IE matrices. In addition, the last stage 
employed the QSPM matrix to determine strategic decisions.

Data collection techniques in this study employed a triangulation technique from three techniques, namely:

1) Observation. This study conducted direct observations to the research object, which is observing the service and production processes directly on Soerya Bakery Tulungagung.

2) Interview. This study conducted interviews by administering a question and answer session to Soerya Bakery Tulungagung owner as well as to the service department employees.

3) Literature Study. Literature study in this research was collecting secondary data obtained from books, previous research journals, and articles from reputable official websites and social media.

\section{RESULTS AND DISCUSSION}

Soerya Bakery Tulungagung is one of the Small and Medium Enterprises (SMEs) located at Jl. MT Haryono No. 103 Bago, Tulungagung. It has been operating for more than six years. The location is right on the edge of the highway, which is highly strategic and accessible. In its early days, Soerya Bakery only produced bread; however, along with the development of technology, market demand, and the rapid competition, the business owner created some innovations, such as producing ice cream, pudding, drinks, and even providing a cafe at the business venue. Nevertheless, business competition relentlessly increases. Many new bakeries and cafés provide more convenient and attractive menu variants, places and facilities. Thus, Soerya Bakery requires an ideal and appropriate marketing strategy to increase competitiveness.

According to Hunger and Wheelen (2012), in formulating a marketing strategy, companies have to pay attention to the affecting environment in order to be successful in the long run. This environment is divided into two; internal and external environment. Internal strategy factors are demonstrated in Table 1, while external strategy factors are viewed in Table 2.

Table 1. Internal Strategy Factors

\section{Strengths}

Weaknesses

\begin{tabular}{|c|c|c|c|}
\hline 1) & $\begin{array}{l}\text { Guaranteed product quality } \\
\text { due to new daily products }\end{array}$ & 1) & $\begin{array}{l}\text { Lack of promotion both } \\
\text { online and offline }\end{array}$ \\
\hline 2) & $\begin{array}{l}\text { Affordable prices for all } \\
\text { people }\end{array}$ & 2) & $\begin{array}{l}\text { Unattractive room } \\
\text { decoration }\end{array}$ \\
\hline 3) & $\begin{array}{l}\text { Various products, not only } \\
\text { bread but also ice cream, } \\
\text { pudding and drinks }\end{array}$ & 3) & $\begin{array}{l}\text { Rarely offering any } \\
\text { discounts or promos to } \\
\text { consumers. }\end{array}$ \\
\hline 4) & $\begin{array}{l}\text { Good company } \\
\text { management }\end{array}$ & 4) & $\begin{array}{l}\text { On busy days, the service } \\
\text { becomes slow. }\end{array}$ \\
\hline 5) & $\begin{array}{l}\text { Strategic and accessible } \\
\text { location }\end{array}$ & 5) & $\begin{array}{l}\text { Parking space is not } \\
\text { spacious enough. }\end{array}$ \\
\hline 6) & Having resellers & & \\
\hline 7) & $\begin{array}{l}\text { Bakery provides café } \\
\text { facilities }\end{array}$ & & \\
\hline
\end{tabular}

Table 2. External Strategy Factors

Soerya Bakery Tulungagung

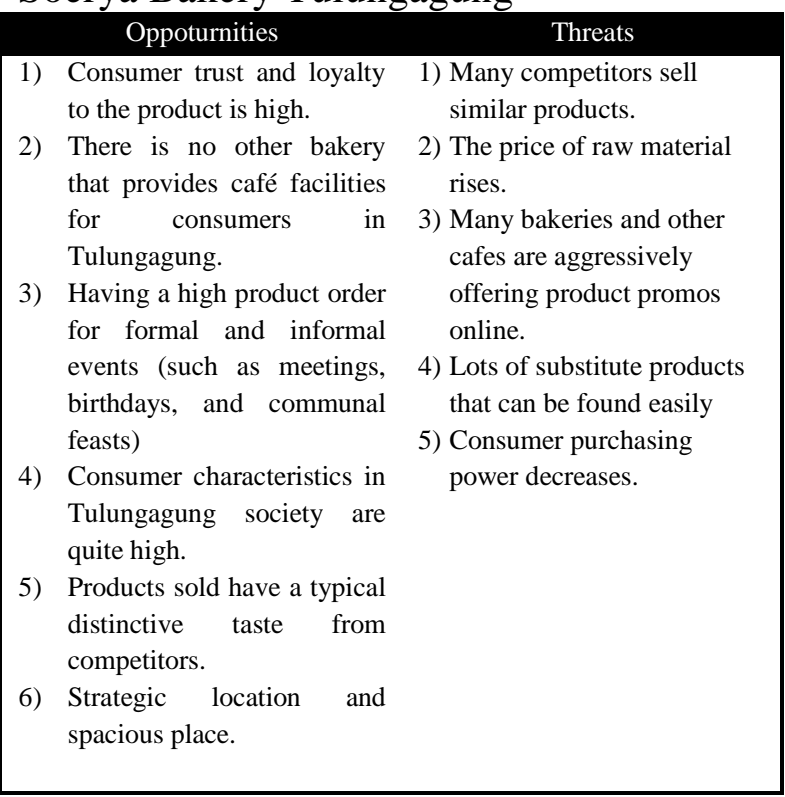

Input Analysis

Internal Factor Evaluation (IFE) Matrix A more detailed result of the IFE matrix analysis described in Table 3: 
Table 3. IFE Matrix Analysis Results

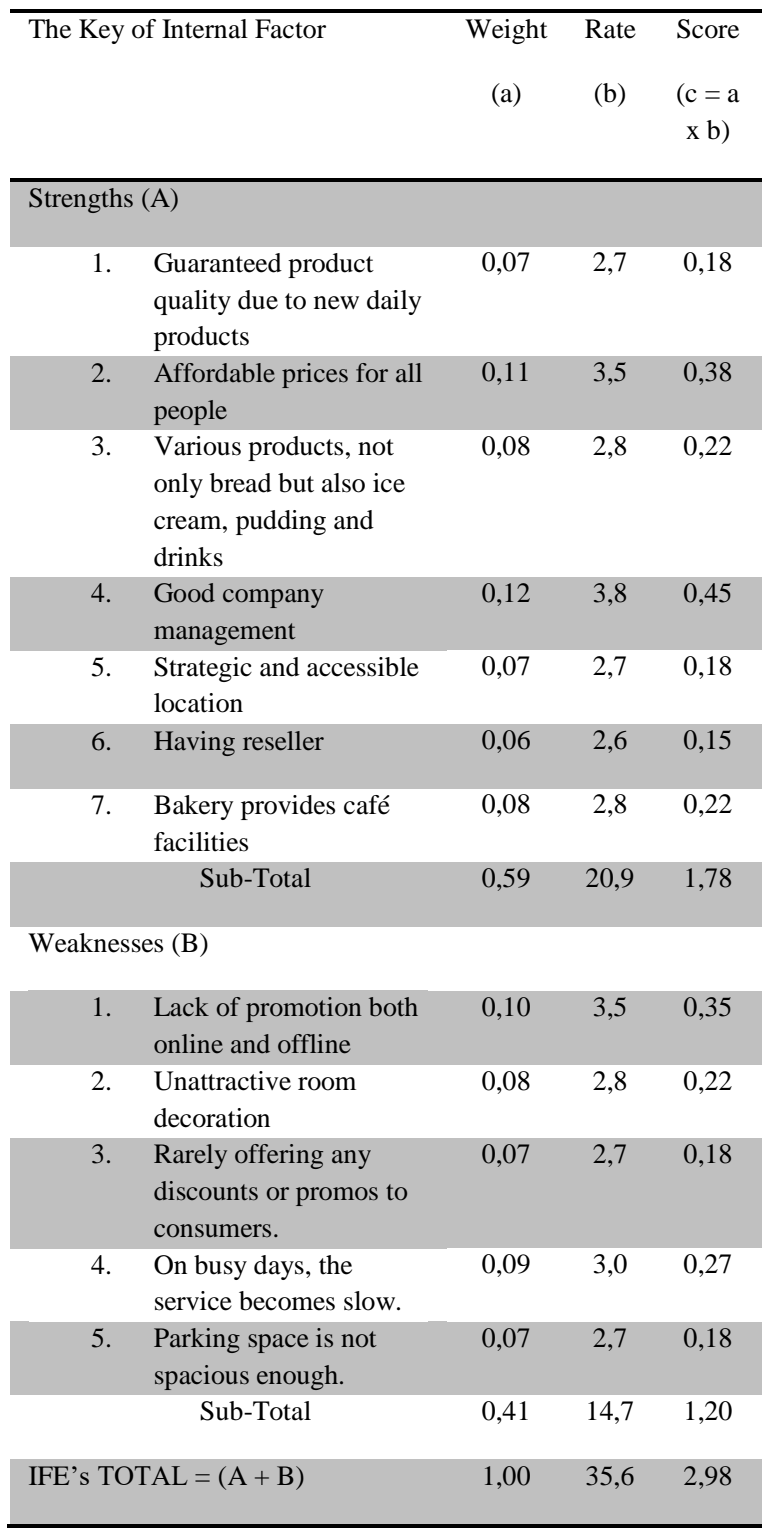

From the described matrix above, several conclusions are drawn to describe the conditions of the Soerya Bakery Tulungagung company, which are: (a) On the strength factor, the highest score was 0.12 , and a rating of 3.8 , with a total score of 0.45 . In other words, it has proper company management. Soerya Bakery Tulungagung management is monitored and evaluated directly by the company's owner. It is good in finance, administration, production and marketing. As a result, there is an increase in sales every year. They also have never experienced bankruptcy while running the business. Therefore, the owner of Soerya Bakery Tulungagung has proper company management. (b) On the weakness factor, the highest score was 0.10 and a rating of 3.5 with a score of 0.35. It identifies that it lacks promotion both online and offline. Soerya Bakery Tulungagung rarely offers some promotions both online and offline. For social media, they have Instagram, Facebook, and Google Business; nevertheless, they never update their product information and promotions. (c) In the IFE matrix table, a total value obtained was 2.98. It indicates that Soerya Bakery Tulungagung is in average position in utilizing its strengths and is able to overcome existing weaknesses.

\begin{tabular}{|c|c|c|c|c|}
\hline \multicolumn{2}{|c|}{ The Key of External Factor } & $\begin{array}{l}\text { Weight } \\
\text { (a) }\end{array}$ & $\begin{array}{l}\text { Rate } \\
\text { (b) }\end{array}$ & $\begin{array}{l}\text { Score } \\
(\mathrm{c}=\mathrm{a} \\
\mathrm{x} \text { b) }\end{array}$ \\
\hline \multicolumn{5}{|c|}{ Opportunities (A) } \\
\hline 1 & $\begin{array}{l}\text { Consumer trust and } \\
\text { loyalty to the product is } \\
\text { high. }\end{array}$ & 0,10 & 3,0 & 0,30 \\
\hline 2. & $\begin{array}{l}\text { There is no other bakery } \\
\text { that provides café } \\
\text { facilities for consumers in } \\
\text { Tulungagung. }\end{array}$ & 0,12 & 4,0 & 0,48 \\
\hline 3. & $\begin{array}{l}\text { Having a high product } \\
\text { order for formal and } \\
\text { informal events (such as } \\
\text { meetings, birthdays, and } \\
\text { communal feasts) }\end{array}$ & 0,08 & 2,9 & 0,23 \\
\hline 4. & $\begin{array}{l}\text { Consumer characteristics } \\
\text { in Tulungagung society } \\
\text { are quite high. }\end{array}$ & 0,07 & 2,8 & 0,19 \\
\hline 5. & $\begin{array}{l}\text { Products sold have a } \\
\text { typical distinctive taste } \\
\text { from competitors. }\end{array}$ & 0,08 & 2,9 & 0,23 \\
\hline 6. & $\begin{array}{l}\text { Strategic location and } \\
\text { spacious place. }\end{array}$ & 0,07 & 2,8 & 0,19 \\
\hline & Sub-Total & 0,52 & 18,4 & 1,62 \\
\hline \multicolumn{5}{|c|}{ Threaths (B) } \\
\hline 1. & $\begin{array}{l}\text { Lack of promotion both } \\
\text { online and offline }\end{array}$ & 0,11 & 3,5 & 0,38 \\
\hline 2. & $\begin{array}{l}\text { Unattractive room } \\
\text { decoration }\end{array}$ & 0,09 & 2,8 & 0,25 \\
\hline 3. & $\begin{array}{l}\text { Rarely offering any } \\
\text { discounts or promos to } \\
\text { consumers. }\end{array}$ & 0,12 & 3,9 & 0,46 \\
\hline & $\begin{array}{l}\text { On busy days, the service } \\
\text { becomes slow. }\end{array}$ & 0,08 & 2,8 & 0,22 \\
\hline & $\begin{array}{l}\text { Parking space is not } \\
\text { spacious enough. }\end{array}$ & 0,08 & 3,0 & 0,24 \\
\hline & Sub-Total & 0,48 & 16 & 1,55 \\
\hline EFE's T & $\mathrm{TAL}=(\mathrm{A}+\mathrm{B})$ & 1,00 & 34,4 & 3,17 \\
\hline
\end{tabular}

From the EFE matrix, several 
conclusions drawn to describe the condition of the company, namely:

a) In the opportunity factor, the highest score was 0.12 and a rating of 4.0, with a total score of 0.48 . It turns out that there are no other bakeries that provide café facilities for consumers in Tulungagung. Not only a bakery, but Soerya Bakery Tulungagung also provides a cafe for customers. For the products, they sell not only bread but also ice cream, pudding, and drinks. This opportunity will be a good strategy because nowadays lots of people, both young and old, like to spend their time (hanging out) in a cafe.

b) In the threat factor, the highest score was 0.12 and a rating of 3.9 with a score of 0.46 . There are many bakeries and other cafés which are aggressively providing product promos online. In this digital era, many people use social media to offer a promotion that significantly affects the attractiveness and competitiveness of companies.

c) In the EFE matrix table, the total value was 3.17. It indicates that Soerya Bakery Tulungagung is in a high position in taking advantages of existing opportunities and ready to overcome any threats.

Matching Stage, SWOT

(Strengths, Weakness, Opportunities, and Threats) Matrix
Table 5. SWOT Matrix Analysis

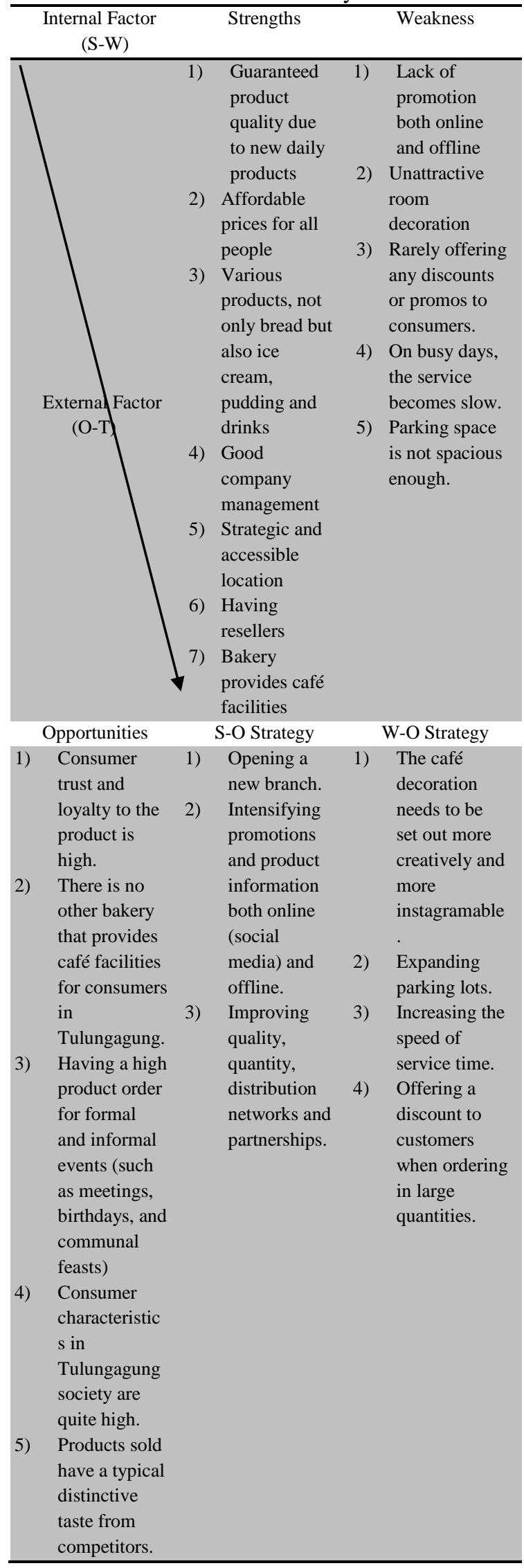


Jurnal Ilmiah Ekonomi dan Bisnis

Vol. 18. No.2,September 2021 : 156-165

EISSN : $2442-9813$

ISSN : $1829-9822$

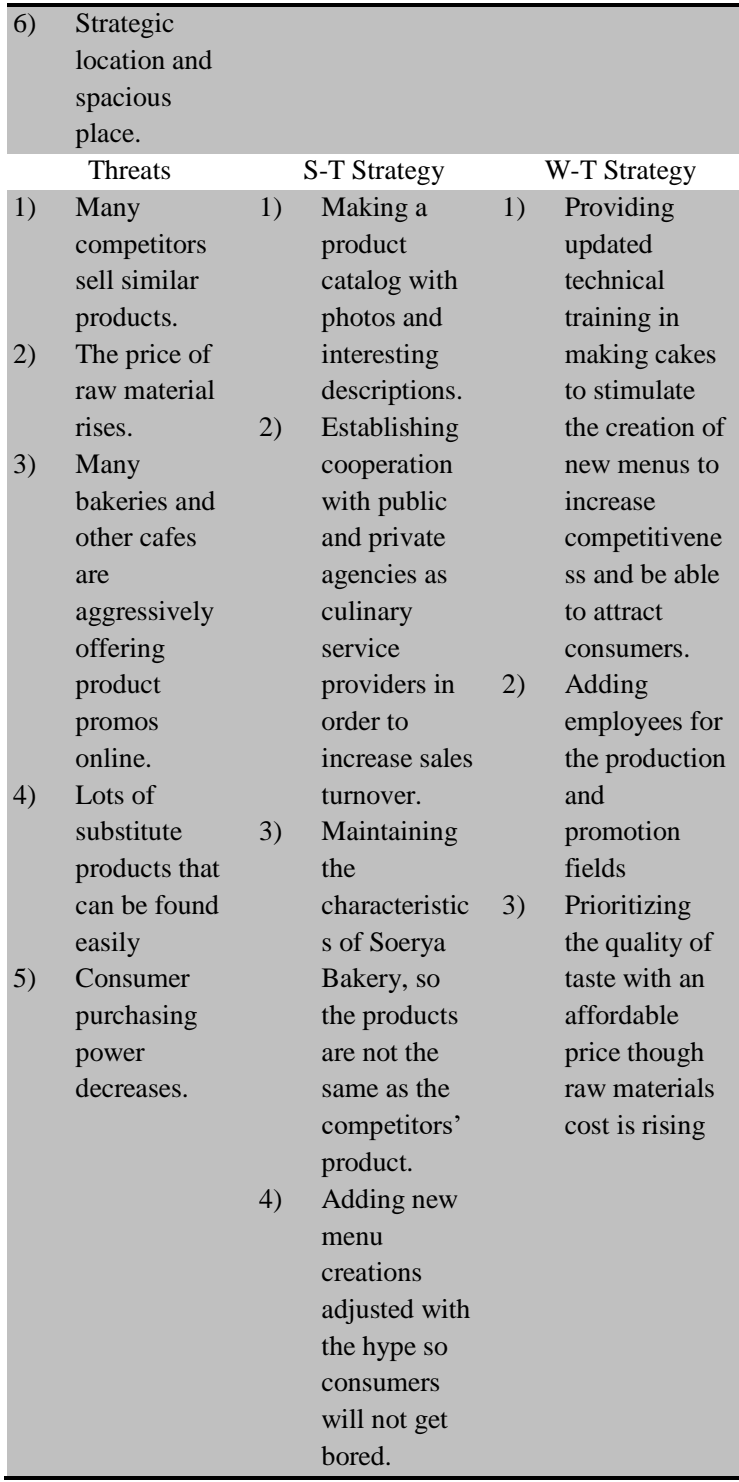

The SWOT matrix above produces

four alternative strategies cell for marketing development. The S-O strategy utilizes the company's internal strengths to take advantage of the existing external opportunities at Soerya Bakery Tulungagung. Meanwhile, the W-O strategy aims to correct weaknesses by exploiting external opportunities. Additionally, the S-T strategy utilizes the company's strengths to avoid or reduce the impact of external threats that may occur. Lastly, the W-T strategy is a defensive tactic (a technique in a business to maintain the company's position in the market) aims at reducing internal weaknesses and avoiding external threats.
IE Matrix (Internal External)

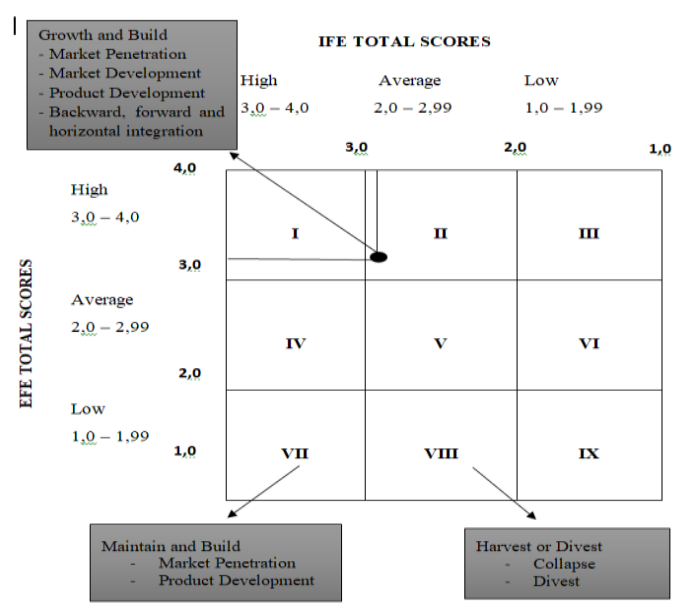

The application of IE Matrix Analysis aims to determine the strategic position and alternative strategies for the company in order to be able to face competition and business growth in the future. The results obtained from the IFE and EFE matrices were utilized to compile the IE matrix so that we might identify the position of Soerya Bakery Tulungagung. With this position, it can foresee what strategy is suitable for Soerya Bakery Tulungagung.

The average total score on the IFE matrix was 2.98, while the EFE matrix was 3.17. From the results of the IE matrix analysis on the figure, Soerya Bakery Tulungagung was enlisted in cell II namely Growth and Build. An average cell was for IFE matrix, and a high cell was for EFE matrix. In this position, Soerya Bakery Tulungagung is capable of conducting intensive strategies and integrative strategies.

An intensive strategy is to penetrate the market by expanding market share through marketing/promotion efforts. In addition, this strategy is also to develop a market by expanding market share, which is geographically, it belongs to new regions or new targets. Besides, developing products by modifying/creating new 
products that are different from competitors, is generally executed when the product is in a saturated position. Furthermore, in cell II there is an integrative strategy, namely forward strategy, backward integration and horizontal integration. The forward strategy is to prepare product innovation, quality improvement, and service facilities. The backward integration is an evaluation of the strategies that have been carried out previously, while horizontal integration is executed through quality control.

Decision Stage, QSPM Matrix

Internal and external environmental analysis is a critical foundation for decision making of strategy formulation. QSPM is the final step in the framework of the strategy formulation analysis. At this stage, it objectively indicates the best strategy and which one must be implemented. QSPM employs the input analysis from stage 1 and the matching results from stage 2 analysis to facilitate objectively in determining or directing which strategies need to be carried out immediately among the alternative strategies.

Based on matching matrix analysis (IFE, EFE, SWOT, IE), it can be concluded that the strategies that must be implemented are in the form of market penetration and product development. Concerning alternative strategies that have been compiled in the SWOT matrix, this study took three strategies to be compared by employing QSPM. (1) Strategy 1

Intensifying promotions and product information both online (social media) and offline. (2) Strategy 2 : Improving quality, quantity, distribution networks and partnerships. (3) Strategy 3 :

Opening a new branch.
Table 6. QSPM Matrix

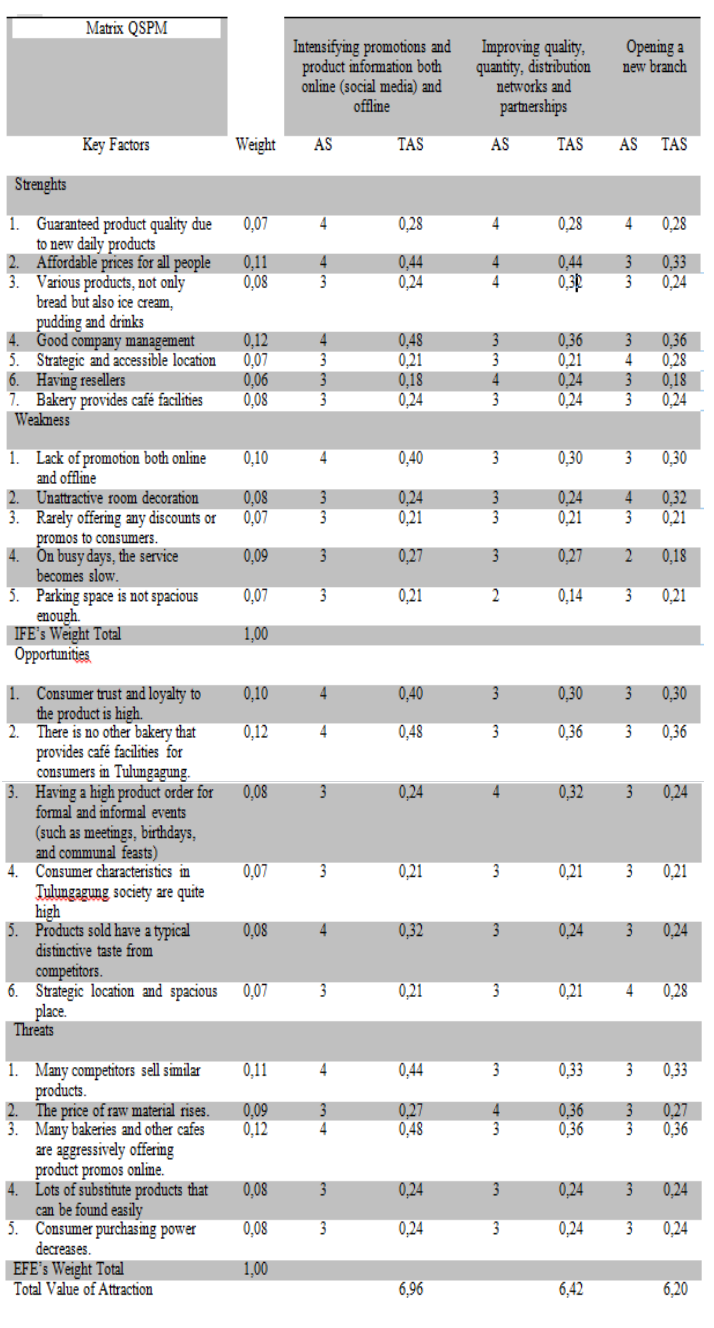

The table above clarifies that the results of the primary data analysis with the QSPM (Quantitative Strategic Planning Matrix) on the marketing strategy business of Soerya Bakery Tulungagung include: (a) TAS value obtained in alternative strategy I was 6.96, which means an alternative strategy that must be implemented is to intensify promotions and product information both online (social media) and offline. In this digital era, social media is a marketing tool that quickly acknowledged and easily accessed by everyone. Alves et al., (2016); Luo \& Zhang (2013); and Yu et al., (2013) research results concluded that social media marketing strategies possess the capacity to influence the market value of companies and businesses. Social media enables and empowers word of mouth 
information as a capacity to generate additional sales. Accordingly, online business promotion is highly significant to practice. Offline promotion is also substantial to support cooperation from an organization or institution as well as to increase the number of resellers. Offline promotion can be execute by creating attractive product catalogs that can be utilized as proposals for partnerships, as well as placing various posters or banners in strategic places to introduce Soerya Bakery products. (b) The TAS value reached in alternative strategy II was 6.42, which implies that the required alternative strategy that should be implemented is to improve the quality, quantity, distribution network, and partnership. It is significantly crucial for Soerya Bakery Tulungagung as it is related to customer trust and loyalty. Increasing the quality and quantity of bread production at Soerya Bakery is inseparable from the existence of production control management, which includes human resources (employees), raw materials, production equipment, and marketing distribution. This alternative is coherent with the results of Afridhal's research (2017), which found out that the acquisition of TAS value in the alternative strategy II was 6.25. It identifies that an alternative strategy that should be carried out in the research is to improve and maintain the quality and quantity of tanjong bread and efficiency in the use, facilities and infrastructure production.

The TAS value gained in alternative strategy III was 6.20 , which means that opening a new branch is an alternative strategy to applied. Opening a business branch is a sign of business success. By opening a new branch, a business person can demonstrate their seriousness in expanding marketing targets and competitiveness in competition. This strategy is related to good company management, including being able to meet market demand; target suitability; good production, marketing and sales processes; and resources.

\section{CONCLUSIONS AND SUGGESTION}

The study employed mixed-methods in both qualitatively and quantitatively. It had successfully analyzed internal and external conditions through the SWOT matrix to determine the proper strategy to improve the competitiveness of Soerya Bakery Tulungagung business. The results indicated that the value for the Internal Factor Evaluation (IFE) matrix was 2.98 (average position) and the External Factor Evaluation (EFE) was 3.17 (moderate position). Furthermore, from the Internal External Matrix (IE), it can be concluded that growth and build strategy is required to apply, comprising of an intensive strategy (market penetration, market development, and product development) and integrative strategy (forward, backward, and horizontal integration). Whereas, the priority strategies that can be applied in developing the business based on the QSPM matrix is to intensify promotions and product information both online (social media) and offline; to improve the quality, quantity, distribution network, and partnerships; and to open a new branch.

The researchers selected Soerya Bakery Tulungagung, a Small and Medium Enterprise, as an object of research. Nonetheless, it is possible to employ other research objects for further researches, such as start-ups or companies. Hence, it may produce different kinds of research and enrich science.

\section{REFERENCES}

Adewale et al. (2013). Impact of Marketing Strategy on Business Performance A Study of Selected Small and Medium Enterprises (Smes) In Oluyole Local Government, Ibadan, Nigeria. Journal of Business and Management, 11(4), 59-66. 
Afridhal, Muhammad. (2017). Strategi Pengembangan Usaha Roti Tanjong Di Kecamatan Samalanga Kabupaten Bireuen. Jurnal Sains Pertanian, 1(3), 223 -233 .

Alves Helena et al. (2016). Social Media Marketing: A Literature Review and Implications: Implications of Social Media Marketing. Journal of Psychology and Marketing, 33(12), 1029-1038.

Anggraeni, dkk. (2017). Strategi Peningkatan Daya Saing Usaha Kecil Menengah Berbasis Olahan Ikan di Indonesia: Suatu Tinjauan. Journal Industrial Services, 3(1), 331-341.

Ataman et al. (2010). The Long-Term Effect of Marketing Strategy on Brand Sales. Journal of Marketing Research, 47(10), 866 -882 .

Barney, J. B., Wright, M., and Ketchen, D. J. (2001). The Resource-based View of The Firm: Ten Years After 1991. Journal of Management, 27, 625.

CNCB Indonesia. (2019). Ini 10 Negara dengan PDB Terbesar di Dunia, RI Urutan Berapa? Diakses dari https://www.cnbcindonesia.com/ market/20190930185655-20103299/ini-10-negara-denganpdb-terbesar-di-dunia-ri-urutanberapa

David, F. R., \& David, F. R. (2017). Strategic Management: A Competitive Advantage Approach, Concepts and Cases (16th Edition). New Jersey, United States: Pearson Education Inc.

Gruel, Emet. (2017). Swot Analysis: A Theoretical Review. Journal of International Social Research, 10(51), $994-1006$.
Harris, Lisa and Alan Rae. (2010). The Online Connection: Transforming Marketing Strategy for Small Businesses. Journal of Business Strategy, 31(2), 4 - 12.

Heerde et al. (2013). Price and Advertising Effectiveness over the Business Cycle. Journal of Marketing Research, 50(4), 177 - 193.

Hunger, J.D. dan Wheelen, T.L. (2012). Strategic Management and Bussiness Policy: Toward Global Sustainability (13th Edition). New York: Pearson.

Kompas. (2020). Perekonomian Indonesia berada di Peringkat 7 Dunia. Diakses dari https://www.kompas.tv/article/680 37/perekonomian-indonesiaberada-di-peringkat-7-dunia

Luo, X., \& Zhang, J. (2013). How Do Consumer Buzz and Traffic. Journal of Management Information Systems, 30, 213-238.

Meliala, dkk. (2014). Strategi Peningkatan Daya Saing Usaha Kecil dan Menengah (UKM) Berbasis Kaizen. Jurnal Optimasi Sistem Industri, 13(2), 641- 664.

Ommani, Ahmad Reza. (2011). Strengths, Weaknesses, Opportunities and Threats (SWOT) Analysis For Farming System Businesses Management: Case of wheat farmers of Shadervan District, Shoushtar Township, Iran. African Journal of Business Management, 5(22), $9448-9454$.

Yu, Y., Duan, W., \& Cao, Q. (2013). The impact of social and conventional media on firm equity value: A sentiment analysis approach. Decision Support Systems, 55, 919-926. 